\title{
INFLUENCE OF TEMPERATURE ON RECOMBINATION IN YEAST
}

\author{
J. R. JOHNSTON * and R. MORTIMER \\ Donner Laboratory and Division of Medical Physics, \\ University of California, Berkeley
}

Received 8.ix.66

\section{INTRODUCTION}

THE effect of temperature upon recombination frequency has been the object of numerous investigations since the pioneer work of Plough (I9I7). The result obtained by Plough with Drosophila melanogaster, namely a $U$-shaped temperature function of crossing over with maxima around $9^{\circ} \mathrm{C}$. and $32^{\circ} \mathrm{C}$. and a minimum around $22^{\circ} \mathrm{C}$. for certain chromosome regions (Smith, 1936), has since been substantially confirmed (for example, Stern 1926; Kikkawa, 1934; Hayman and Parsons, 1960). When organisms other than Drosophila have been examined, however, no consistent picture has been obtained. For instance, crossing over in Habrobracon appears independent of temperature (Clark, 1943) and in Ustilago hordei, a minimum frequency at $8^{\circ}$ G. has been found (Hüttig, 1931). In Neurospora crassa, various results have been obtained (Rifaat, I959; Towe and Stadler, 1964; McNelly-Ingle, Lamb and Frost, 1966) and it appears likely that genetic background exerts an important influence (Lawrence, 1963). In general, a change of recombination frequency with temperature has appeared to be confined to regions close to the centromere. In both Drosophila (Lawrence, I958) and Neurospora (McNelly-Ingle, Lamb and Frost, 1966), however, certain regions removed from the centromere have shown an increased frequency of recombination at lower temperatures. The purpose of the experiments reported here was to investigate the effect of different temperatures upon recombination in a number of regions in hybrid Saccharomyces, in which there is a stable diplophase and little effect upon viability and growth rate when cultures carry many mutant markers.

\section{MATERIALS AND METHODS}

\section{(i) Strains}

The diploid Saccharomyces hybrids investigated had the genotypes $\uparrow$

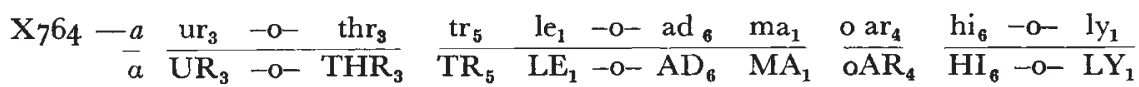

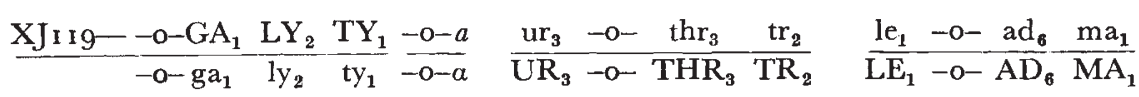

$$
\begin{aligned}
& \begin{array}{lcccc}
-\mathrm{o}-\mathrm{ar}_{4} & \mathrm{thr}_{1} & \mathrm{cu}_{1} & -\mathrm{o}-\mathrm{ser}_{1} & \mathrm{hi}_{8} \\
\hline-\mathrm{o}-\mathrm{AR}_{4} & \mathrm{THR}_{1} & \mathrm{CU}_{1} & -\mathrm{o}-\mathrm{SER}_{1} & \mathrm{HI}_{8}
\end{array}
\end{aligned}
$$

* Present address: Department of Applied Microbiology and Biology, University of Strathclyde, Glasgow, C.I, Scotland.

+ The symbols $a$ and $\alpha$ represent the complementary mating type alleles; ad, ar, hi, le, ly, thr, ser, tr, ty and ur represent ability (upper case) or inability (lower case) to grow in the absence of adenine, arginine, histidine, leucine, lysine, threonine ( $\mathrm{th}_{1}$ ) or threonine plus 


\section{(ii) Media and Procedure}

Sporulation was achieved by growing cultures for two days at $30^{\circ} \mathrm{C}$. on slopes of pre-sporulation medium ( 5 per cent. glucose, 2.3 per cent. Difco Nutrient Agar) and transferring to slopes of sporulation medium $(0.3$ per cent. sodium acetate, 0.02 per cent. raffinose). The latter were incubated at either $25^{\circ} \mathrm{C}$., $15^{\circ} \mathrm{C}$. or $12^{\circ} \mathrm{C}$.

Four-spored asci were dissected after digestion of ascus walls by snail juice (Johnston and Mortimer, 1959) and tetrad analysis of asci with four viable spores performed by replica plating (Lederberg and Lederberg, 1952). Omission, fermentation and copper sensitivity media were as previously described (Hawthorne and Mortimer, I960).

\section{RESULTS AND DISCUSSION}

Sporulation was slower at $15^{\circ} \mathrm{C}$. and $12^{\circ} \mathrm{C}$. (completion of all asci by I0-I 2 days) than at $25^{\circ} \mathrm{C}$. (completion by 3-5 days). The final yield of asci was also less at the lower temperatures (IO-I5 per cent.) than at $25^{\circ}$ C. (20-25 per cent. asci). Tetrads were classified into. parental ditype (PD), non-parental ditype (NPD), and tetratype (T), for the segregation of pairs of linked genes, and into first division segregation (FDS) and second division segregation (SDS) for the segregation of genes with their centromeres. Centromere segregation was determined for each ascus from an examination of the segregation of the different centromere-linked markers in the crosses, i.e. $\mathrm{ur}_{3}, \mathrm{le}_{1}$, $\mathrm{ar}_{4}$ and $\mathrm{hi}_{6}$ for $\mathrm{X}_{764}$, and $\mathrm{ga}_{1}, \mathrm{ur}_{3}, \mathrm{le}_{1}$, and $\mathrm{ar}_{4}$ for XJII9 (Howe, I956; Hawthorne and Mortimer, 1960). The results determined at the different temperatures are presented for both hybrids in tables I and 2. The map distance in centimorgans was calculated for each region and temperature. The results were tested for the statistical significance of differences of recombination at the different temperatures.

These experiments permit the following conclusions. Firstly, the recombination frequency of many chromosome regions of yeast appears to be independent of temperature. These regions include some which are close to centromeres $\left(\mathrm{c}-\mathrm{ur}_{3}, \mathrm{c}-\mathrm{ar}_{4}\right)$ and others which are distal $\left(\mathrm{ly}_{2}-\mathrm{ty}_{1}, \mathrm{thr}_{3}-\mathrm{tr}_{2}, \mathrm{ar}_{4}-\mathrm{thr}_{1}, \mathrm{thr}_{1}-\mathrm{cu}_{1}\right)$. Other chromosome regions in which recombination appears independent of temperature contain lengths both close to and considerably removed from centromeres (c-thr ${ }_{3}$ and $\left.\mathrm{c}-\mathrm{ly}_{1}\right)$. In these regions, however, an effect of temperature upon a short length adjacent to the centromere could be masked by the greater but unchanged recombination frequency of the remaining length removed from the centromere. Additional markers more closely linked with respective centromeres are required for further investigation.

Other regions of these strains, however, show a significant response to the variation of sporulation temperature. The effect observed is consistently a reduction of recombination frequency at $15^{\circ} \mathrm{C}$. or

methionine $\left(\mathrm{thr}_{\mathrm{g}}\right)$, serine, trytophan, tyrosine plus phenylalanine, and uracil. ma/MA and $\mathrm{ga} / \mathrm{GA}$ represents inability/ability to ferment maltose and galactose respectively. cu/CU represents inability/ability to grow in the presence of $60 \mu \mathrm{g} . / \mathrm{ml}$. of copper. The mapping of these genes has been described (Hawthorne and Mortimer, I96o; Mortimer and Hawthorne, 1966). 


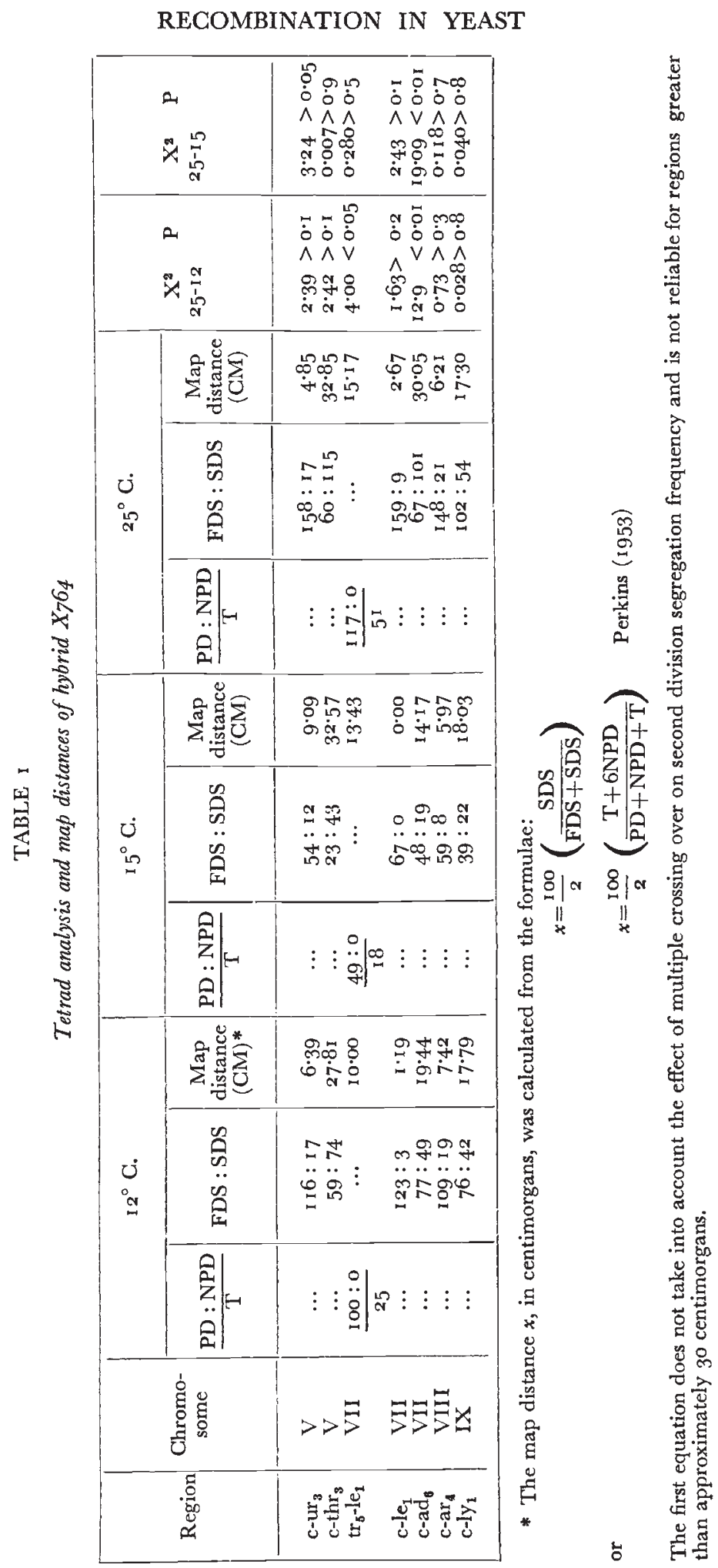




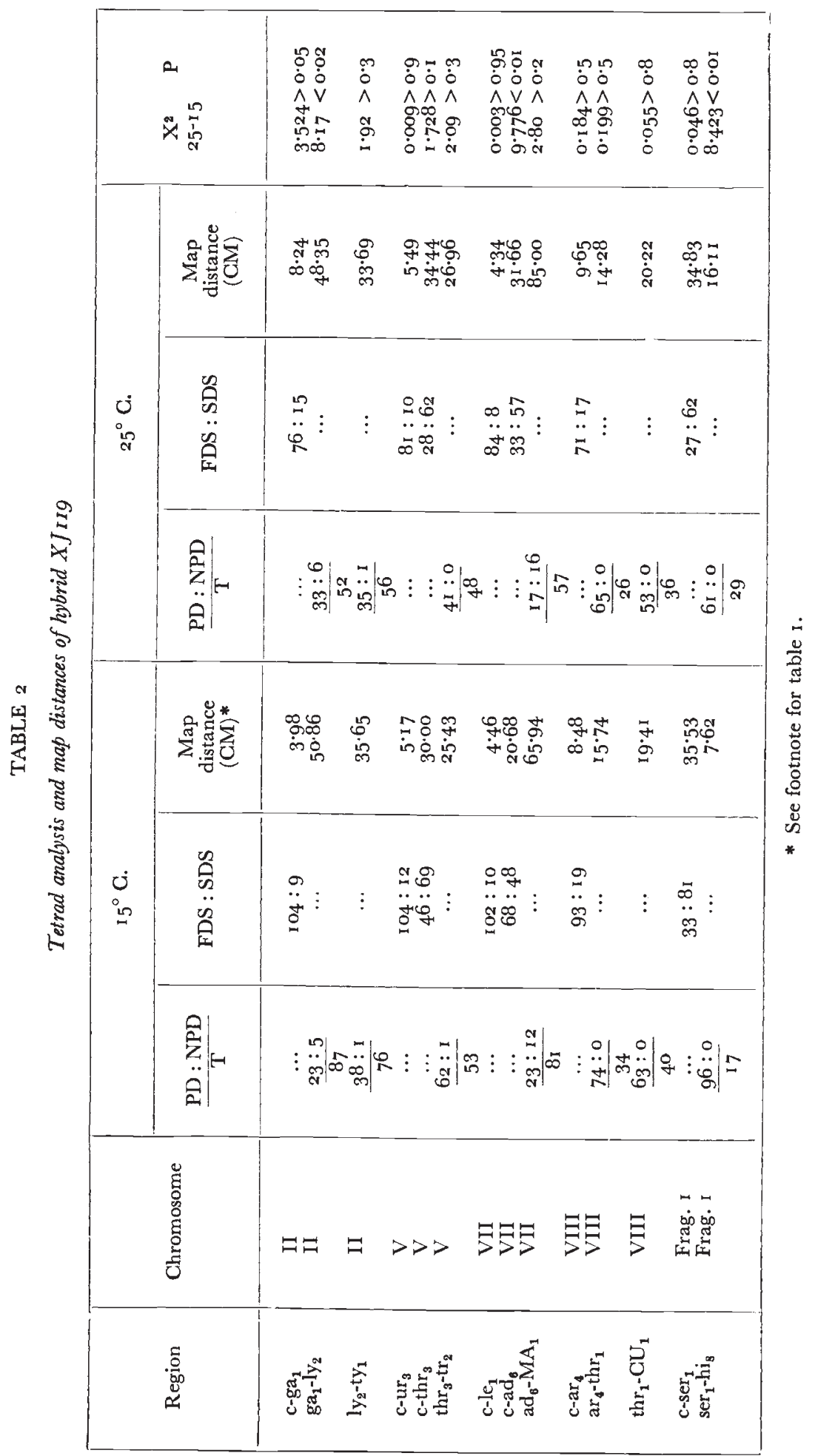


$12^{\circ} \mathrm{C}$. compared with $25^{\circ} \mathrm{C}$. The most striking effect is seen in the region $\mathrm{c}-\mathrm{ad}_{6}$ of linkage group VII, in which the frequency of recombination is reduced to $30-50$ per cent. of its value at $25^{\circ} \mathrm{C}$. in both hybrids. The result is doubly interesting in that $\mathrm{c}-\mathrm{ad}_{6}$ is a relatively long region and it is unlikely therefore that the effect of temperature is confined to a length closely linked to the centromere. Another marked region of chromosome VII may be affected in similar fashion since crossing over is apparently reduced at $12^{\circ} \mathrm{C}$. in the region $l_{1_{1}}-\operatorname{tr}_{5}$ of hybrid $X_{7} 64$. There is, however, no evidence of a corresponding reduction in region $c-l e_{1}$ of either hybrid. The increase in recombination frequency observed between $15^{\circ} \mathrm{C}$. and $12^{\circ} \mathrm{C}$. for the region $\mathrm{c}-\mathrm{ad}_{6}$ is not statistically significant and therefore apparently does not indicate an inflexion point between $25^{\circ} \mathrm{C}$. and $12^{\circ} \mathrm{C}$.

In XJI I 9, recombination in the centromere region c-ga ${ }_{1}$ of chromosome II is reduced approximately twofold at $15^{\circ} \mathrm{C}$. Although this difference is not statistically significant $(P>0.05)$, it becomes so $\left(\chi^{2}=6.25, \mathrm{P}<0.02\right)$, if $8.24 \mathrm{CM}$ is taken as the standard map distance at $25^{\circ}$ C. This procedure seems justified by the supporting data of Hawthorne and Mortimer (I960), who give a SDS value of I 5.3 per cent. to region c-ga ${ }_{1}$. Another approximately twofold reduction in crossing over at ${ }^{\circ} 5^{\circ} \mathrm{C}$. is obtained in XJi $\mathrm{X}$. This effect is observed in region $\mathrm{ser}_{1}-\mathrm{hi}_{8}$ which is well removed from the centromere. This result and the reduction in recombination in the extended region c-ad ${ }_{6}$, demonstrate that the effects of temperature upon crossing over in yeast are not confined to regions close to a centromere. In this respect these findings in yeast confirm those of Lawrence (1958, 1963) in Drosophila and of McNelly-Ingle, Lamb and Frost (1966) in Neurospora.

Other experiments with Drosophila (Plough, I92 I; Graubard, I 934; Politzer, 1940), Neurospora (Rifaat, I959; Towe and Stadler, 1964) and Podospora (Rizet and Engelmann, 1949) have suggested that the effect of temperature upon crossing over is concentrated in regions close to a centromere.

In the regions sensitive to a lowered temperature, the effect in yeast is opposite to that found in Drosophila (Plough, 1917; Smith, 1936), in which lower temperatures increase the degree of crossing over in sensitive regions. This effect in yeast is similar, however, to that in Ustilago hordei (Hüttig, I93I) and to certain findings in Neurospora (Rifaat, I959), in which some crosses showed less recombination at I $7^{\circ}$ C. than at $25^{\circ}$ C. Other experiments with Neurospora (Lawrence, 1958, 1963; Towe and Stadler, 1964; McNelly-Ingle, Lamb and Frost, i 966$)$, however, in which reduced temperatures of $15^{\circ} \mathrm{C}$. and I $8^{\circ} \mathrm{C}$. were used, have given results similar to those with Drosophila, i.e. increased recombination frequency at lower temperature. Compared with these results, yeast shows an opposite effect to Neurospora. One possible explanation of these variations is that there exists genetic control over the response of recombination frequency to changes in temperature. Such control is indicated in the different results between 
crosses of Neurospora (Rifaat, 1959) and Podospora anserina (Rizet and Engelman, 1949). The above experiments with yeast do not permit any conclusion to be drawn in this respect.

\section{SUMMARY}

1. Two diploid hybrids of Saccharomyces cerevisiae with marked regions on several linkage groups have been sporulated at $25^{\circ} \mathrm{C}$. and $15^{\circ} \mathrm{C}$., and one of them at $12^{\circ} \mathrm{C}$. also. Asci have been subjected to tetrad analysis and recombination frequencies compared for the different temperatures.

2. The frequency of crossing over in a majority of regions is not significantly different at these temperatures.

3. The regions unaffected by a lower temperature include those close to, and distant from a centromere.

4. Recombination frequency of a few regions is approximately halved by sporulation at reduced temperature. This effect is not confined to regions in the vicinity of a centromere.

5. The opposite effect has been found in Drosophila. Similar and different results have been obtained with $\mathcal{N}$ eurospora crassa.

\section{REFERENCES}

CLARK, A. M. 1943. Linkage relations in Habrobracon and the effects of temperature, X-irradiations, and age on crossing over. Proc. Pa. Acad. Sci., 17, 47-64.

GRAUBARD, M. A. 1934. Temperature effect on interference and crossing over. Genetics, 19, 83-94.

HAWTHORNe, D. C., AND MoRTimer, R. K. 1960. Chromosome mapping in Saccharomyces: centromere-linked genes. Genetics, 45, 1085-I I 10.

HAYMAN, D. L., AND PARSONS, P. A. I960. The effect of temperature, age and an inversion on recombination values and interference in the $\mathrm{X}$-chromosome of Drosophila melanogaster. Genetica, 32, 74-88.

HoWE, H. B. 1956. Crossing over and nuclear passing in Neurospora crassa. Genetics, 41,6 I $0-622$.

HÜтTIG, W. I93I. Uber den Einfluss der Temperatur auf die Keimung und Geschlechterverteilung bei Brandpilzen. Z. Bot., 34, 529-577.

JOHNSTON, J. R., AND MORTIMER, R. K. 1959. Use of snail digestive juice in the analysis of yeast tetrads. F. Bacteriol., 78, 292.

kIKKAWA, H. 1934. Studies on non-inherited variation in crossing over in Drosophila. 7. Genet., 28, 329-348.

LAWRENCE, M. J. I 958. Genotypic control of crossing-over in the first chromosome of Drosophila melanogaster. Nature, $182,889-890$.

LAWRENGE, M. J. 1963. The control of crossing-over in the X-chromosome of Drosophila melanogaster. Heredity, $18,27-46$.

LEDERBERG, J., AND LEDERBERG, E. M. 1952. Replica plating and indirect selection of bacterial mutants. F. Bacteriol., $63,399-406$.

MGNELLY-INGLE, G. A., LAMB, B. C., AND FROST, L. G. I966. The effect of temperature on recombination frequency in Neurospora crassa. Genet. Res., 7, 169-183.

MORTIMER, R. K., AND HAWTHORNE, D. G. 1966. Genetic mapping in Saccharomyces. Genetics, 53, I65-I 73 .

PERKINS, D. D. 1953. The detection of linkage in tetrad analysis. Genetics, 38, I87-197. 
PLOUGH, H. H. 1917. The effect of temperature on crossing over in Drosophila. 7. exp. Zool., 24, 143-209.

PLOUGH, н. H. 1921. Further studies on the effect of temperature on crossing over. 7. $\exp$. Zool., 32, 187-202.

POLITZER, o. 1940. Veranderungen der cross-over haufigkeit durch Einwirkung von Temperatur und Alter. Z. indukt. Abstamm. u. Vererblehre, 78, 129-147.

RIFAAT, O. M. 1959. Effect of temperature on crossing over in Neurospora crassa. Genetica, 3o, 31 2-323.

Rizet, G., AND ENGLEMANN, C. 1949. Contribution a l'etude genetique d'un ascomycete tetraspora Podospora anserina. Rev. Cytol. Paris, II, 201-304.

sмiтн, н. F. 1936. Influence of temperature on crossing over in Drosophila. Nature, $138,329-330$.

STERN, c. 1926. An effect of temperature and age on crossing over in the first chromosome of Drosophila Melanogaster. Proc. natl. Acad. Sci. Wash., 12, 530-532. TOWE, A. M., AND STADLER, D. R. 1964. Effects of temperature on crossing over in Neurospora. Genetics, 49, 577-583. 